\title{
The role of leadership in regional climate change adaptation: A comparison of adaptation practices initiated by governmental and non-governmental actors
}

\author{
Sander Meijerink, Sabina Stiller, E. Carina H. Keskitalo, Peter Scholten, \\ Robert Smits and Frank van Lamoen
}

\begin{abstract}
This paper aims to better understand the role of leadership in regional climate change adaptation. We first present a framework, which distinguishes five functions of leadership within inter-organizational networks: the connective, enabling, adaptive, political-administrative and dissemination functions. Next, we compare the role of leadership in two examples of regional adaptation practices which were initiated by governmental actors with two examples which were initiated by non-governmental actors. The case studies are located in the Netherlands, Germany and the UK. Our research question is twofold: to what extent can the five functions of leadership be identified in practices of climate change adaptation, and are there differences in the patterns of leadership between adaptation practices which are initiated by governmental and by non-governmental actors? The study shows that although all leadership functions were fulfilled in all four cases, patterns of leadership were different and the fulfilment of leadership functions posed different challenges to non-governmental actors and governmental actors.
\end{abstract}

Key words | adaptation to climate change, complexity theory, leadership, multi-level governance, water governance

\author{
Sander Meijerink (corresponding author) \\ Radboud University Nijmegen, \\ Institute for Management Research, \\ PO Box 9108, 6500 HK Nijmegen, \\ The Netherlands \\ E-mail: S.Meijerink@fm.ru.nl \\ Sabina Stiller \\ Wageningen University, Public Administration and \\ Policy Group, \\ PO Box 8130, 6700 EW Wageningen, \\ The Netherlands \\ E. Carina H. Keskitalo \\ Department of Geography and Economic History, \\ Umeå University, \\ 90187 Umeå, \\ Sweden \\ Peter Scholten \\ Academic Alternative - Research, Training \& \\ Advisory Services, \\ The Netherlands \\ Robert Smits \\ Municipality of Schijndel, \\ PO Box 5, 5480 AA Schijndel, \\ The Netherlands \\ Frank van Lamoen \\ Province of Northern Brabant \\ PO Box 90151, 5200 MC 's-Hertogenbosch, \\ The Netherlands
}

\section{INTRODUCTION}

As policies for reducing greenhouse gas emissions are generally considered insufficient to prevent climate change, adaptation to climate change is increasingly recognized as an important aspect of climate policy (IPCC 20I4). Even if greenhouse gas emissions were reduced radically in the short term, it is expected that the climate will continue to change, which will have serious impacts on, among other things, water resources management and agriculture (Wreford et al. 20Io). Because of the recognized need for climate change adaptation, it is not surprising that the governance of climate change adaptation is attracting considerable academic attention as well (Smit \& Wandel 2006; Van
Nieuwaal et al. 2009; Keskitalo 20I0a). In governance studies one may take an institutional perspective and/or an agency perspective. Whereas those taking an institutional perspective will typically ask which new institutional or governance arrangements are needed for realizing climate change adaptation (for example, Biermann et al. (2012), Mees \& Driessen (20II)), those taking an agency perspective may ask what are promising entrepreneurial or leadership strategies. In this paper we take an agency perspective, and focus on the role of leadership in climate change adaptation. Meijerink \& Stiller (2013) have reviewed leadership theories that are relevant to climate change adaptation, and based 
on this, built a framework, which may be used to analyse and monitor the performance of specific leadership functions in concrete examples of climate change adaptation. A main argument underlying their framework is that resources, which are needed for the development and implementation of adaptation policies and practices, are highly fragmented hence such policies and projects need to be developed in inter-organizational networks. The framework distinguishes five essential leadership functions within such inter-organizational networks dealing with climate adaptation: the connective, enabling, adaptive, political-administrative and dissemination functions of leadership.

Our research question is twofold: to what extent can these five functions of leadership be identified in practices of climate change adaptation, and, are there differences in the patterns of leadership between adaptation practices which are initiated by governmental and by non-governmental actors?

To answer these questions, we used a comparative case study design. We selected two regional adaptation practices which were initiated by non-governmental actors and two adaptation practices which were initiated by governmental actors. In the first case study, the WaalWeelde initiative in the Netherlands, a university professor played an important initiating role. The WaalWeelde project aims at combining the creation of room for the river (to accommodate the expected higher river discharges) with an improvement of the spatial quality of the Dutch river landscape. In the second case study, the Manhood Peninsula Partnership in south-east England, two citizens initiated the development. The Manhood Peninsula Partnership aims at the development and implementation of spatial strategies for dealing with sea level rise and coastal erosion. In the third case study, the Deltaplan for the dry rural areas in the southern part of the Netherlands, the initiative was taken by the chairman of a Water Board (a public sub-regional authority for water management). The Deltaplan for the dry rural areas aims at developing and implementing innovative strategies for dealing with water scarcity and droughts. In the fourth and final case study, climate adaptation in northern Hesse, Germany, publicly appointed climate adaptation officers took various adaptation initiatives.

Whereas the initiators of the four adaptation practices differ, the cases are structurally similar in many respects.
All four cases studies are examples of climate change adaptation on the sub-national or regional level. Whereas regional and local actors play a key role in these cases, often they also depend on the national government for realizing their initiatives. Because of institutional fragmentation in all three countries, adaptation practices are shaped in networks in which different levels of government, different policy sectors, public and private partners play a role. We have not included examples of autonomous adaptation, but only cases in which formal governmental policies play an important if not crucial role in developing and/or realizing adaptation strategies. Although all four regional project initiatives studied are aimed at developing new substantive strategies to cope with the adaptation issues at stake, such as land-use changes and the creation of room for the river, they can at the same time be seen as examples of governance innovations, such as new cooperative structures and/or working methods. Finally, all four case studies are situated in north-western Europe and share important institutional characteristics: Germany, the Netherlands and the UK are EU member states, high income countries with a market economy and representative democracy.

Because of the institutional fragmentation, the role of both governmental and non-governmental actors, and the need for developing innovative adaptation strategies, we expect the five leadership functions are present in all four practices of climate adaptation studied. In earlier research, we found striking similarities in the pattern of leadership in the Waalweelde and Manhood cases, two examples of regional climate change adaptation initiated by non-governmental actors (Scholten et al. forthcoming). In this paper, we compare these cases with two cases in which governmental actors have played a major initiating role. We expect that even though all leadership functions are relevant in both categories of cases, their fulfilment poses different challenges to the parties involved. Whereas in the first category of cases governmental actors may demonstrate leadership by responding to an initiative taken by others in a way that further enables this initiative, in the second category of cases government agencies may try to connect people or ideas, and by that initiate and enable an innovation process themselves. Distinguishing these different patterns of leadership in the two categories of cases is 
helpful in learning more about the specific leadership challenges which parties are facing.

To identify specific leadership functions, i.e., to what extent leadership functions have been fulfilled by actors within these cases, detailed process reconstructions were needed. We started by collecting relevant background information on the policies, programmes and/or projects in place. Although this is helpful in learning more about the specific adaptation issues at hand, the parties involved, and formal responsibilities, these documents do not reveal much about the fulfilment of leadership functions. Therefore, we conducted in total 35 in-depth, semi-structured interviews. Respondents were key actors in the networks studied, such as the actors who initiated the project initiatives, who had important decision-making responsibilities or were considered key actors by other parties involved. The appendix provides information on the organizational affiliation of the respondents. The number of respondents for the case study on climate adaptation in northern Hesse is relatively low. We conducted three lengthy in-depth interviews, which provided useful information on the Climate Adaptation Officers (CAOs). In addition, we attempted to interview the CAOs and provided their representative with a questionnaire for this purpose since a (telephone) interview was difficult to schedule. However, the CAOs declined to participate in our study pointing to the, at the time, ongoing KLIMZUG evaluation of the CAOs' working experience. This evaluation, however, proved useful for our case analysis.

All interviews were transcribed and coded using the framework of leadership functions and related leadership tasks, as listed in Table 1. The leadership tasks were thus used as codes, with the coding of the interviews undertaken separately for each case study, and by at least two researchers to ensure inter-coder reliability.

In the next section we will briefly present the framework of leadership functions, the actors who may contribute to either one or more of these functions, and the specific leadership tasks related to the functions. Next, we present concise case histories highlighting those leadership functions which figured in each case study. The final section summarizes the main findings on leadership and discusses similarities and differences in the patterns observed across the two categories of cases.

\section{A FRAMEWORK OF LEADERSHIP FUNCTIONS}

Based on a review of various leadership concepts that are relevant to the issues of climate change adaptation, among which are sustainability leadership (Allen et al. 1998; Wielkiewicz \& Stelzner 20Io), leadership for connectivity (Luke 1998, 2000; Chrislip 2002), policy leadership (Kingdon 1984; Mintrom 1997) and complexity leadership theory (Osborn \& Hunt 2007; Uhl-Bien et al. 2007), Meijerink \& Stiller (2013) developed a framework which may be used to describe and analyse the performance of leadership in specific cases of climate change adaptation. The framework builds on insights from complexity leadership theory but incorporates some elements of the other leadership theories mentioned (for a systematic review of leadership theories and information on the development of the leadership framework for climate change adaptation, see Meijerink \& Stiller (20I3)). Leadership is defined as 'a complex interactive dynamic from which adaptive outcomes (e.g. learning, innovation and adaptability) emerge' (Uhl-Bien et al. 2007).

As our focus in this paper is the empirical application of the framework to four case studies, we confine ourselves to a concise description. It distinguishes five elements which leadership within climate adaptation networks is expected to entail. These are the connective, enabling, adaptive, political-administrative and dissemination leadership functions (see Figure 1). These functions and the actions of individuals contributing to these functions are used as an analytical tool to unravel the complex interactive dynamic of leadership.

Table 1 defines the locus of these leadership functions and their related tasks. The connective function is about making connections between governmental sectors, levels

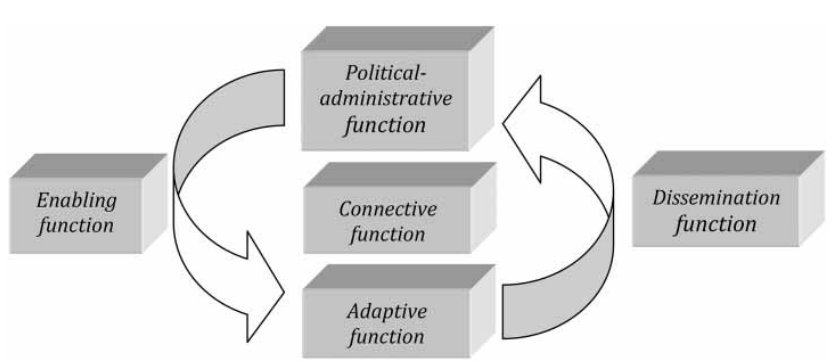

Figure 1 | A framework of leadership functions for climate adaptation (Meijerink \& Stiller 2013) 
Table 1 | Leadership functions, their locus and associated tasks (after Meijerink \& Stiller 2013)

\begin{tabular}{|c|c|c|}
\hline Leadership function & Locus of leadership & Leadership tasks \\
\hline Connective & Positional leaders; Key individuals & $\begin{array}{l}\text { Promote problems and mobilize actors to search for solutions } \\
\text { Bring people together/agree on a collaborative strategy } \\
\text { Stimulate multiple action options/working together/building trust } \\
\text { and legitimacy } \\
\text { Forge agreement/move to action/implement strategies }\end{array}$ \\
\hline Enabling & Positional leaders; Key individuals & $\begin{array}{l}\text { Allow for and stimulate a variety of adaptation strategies and } \\
\text { options } \\
\text { Create a sense of urgency, e.g., by setting deadlines } \\
\text { Insert adaptive tension } \\
\text { Foster interaction }\end{array}$ \\
\hline Adaptive & Network & Development/emergence of new ideas and practices \\
\hline $\begin{array}{l}\text { Political- } \\
\text { administrative }\end{array}$ & $\begin{array}{l}\text { Positional leaders: (elected) politicians and/ } \\
\text { or public managers }\end{array}$ & $\begin{array}{l}\text { Decide on, communicate and monitor the realization of a shared } \\
\text { vision on climate adaptation } \\
\text { Generate and allocate necessary resources for climate adaptation }\end{array}$ \\
\hline Dissemination & Positional leaders; Key individuals & $\begin{array}{l}\text { Insert newly developed ideas (within the CAS) into the network of } \\
\text { positional leaders } \\
\text { Get accepted newly developed ideas }\end{array}$ \\
\hline
\end{tabular}

of government or between public and private parties. Given the cross-cutting nature of most adaptation issues, and the fragmentation of competencies and resources, this leadership function is considered particularly important. Enabling leadership aims to create the necessary conditions for other parties to do their work, to engage in change processes and to develop and experiment with new approaches. The adaptive function concerns the development and emergence of new ideas and practices. As the emergence of new ideas and practices is the (often unexpected) result of the interactions between parties, no specific leadership task is defined for this function. The political-administrative function is the only leadership function which may be fulfilled by positional leaders only. These are defined as actors who possess a formal leadership position, such as a provincial delegate or the head of a department. Because of their position they often have formal decision-making power with regard to adaptation policies and potentially also with regard to allocation of resources for realizing these policies. All other leadership functions may be fulfilled either by positional leaders or by individuals who do not possess formal leadership positions. Finally, the dissemination function of leadership targets the insertion of newly developed ideas and approaches into the network of positional leaders who, as we argued before, are the only ones who decide on formal policies and the allocation of governmental resources. In the next section we will use this framework to analyse whether these leadership functions are present in all four practices of climate change adaptation, and whether we observe differences in the patterns of leadership across the case studies in which either governmental or non-governmental actors were the main initiators of the change process.

\section{LEADERSHIP AND THE DYNAMICS OF REGIONAL CLIMATE ADAPTATION}

This section presents four concise case histories, with a focus on the performance of leadership functions within the regional adaptation networks studied. We first introduce the two cases in which non-governmental actors were the main initiators of the change process: the WaalWeelde initiative in the Netherlands and the Manhood Peninsula Partnership in the UK. Second, we cover the two cases in 
which governmental actors took the initiative for change: the Delta Plan for the dry rural areas in the Netherlands, and climate adaptation in Northern Hesse in Germany.

\section{The WaalWeelde initiative}

In the aftermath of the near floods in the river Rhine of 1993 and 1995, and the fierce societal opposition against the designation of calamity polders, polders which could be flooded on purpose so as to prevent flooding downstream (Warner 2008), the Dutch implementation agency Rijkswaterstaat started to search for alternative governance approaches to develop and implement spatial and infrastructural plans, such as plans to create more room for the river. Within the context of an interactive governance approach, known as the '4B's approach' (which refers to citizens, administrators, civil servants and businesses; in Dutch: burgers, bestuurders, bureaucraten en bedrijven (De Rooij 200o)), a Rijkswaterstaat employee was asked to experiment with an alternative governance approach to deal with river flooding issues in the Province of Gelderland. He started to contact municipalities, provinces and private enterprises, building a small network of people who shared the belief that changes in both the substance and governance of flood risk policies are needed. A main trigger for the new cooperation process was the discomfort with the formal governmental policies to lower the groynes in the river Waal, the main branch of the river Rhine in the Netherlands, to improve the river's discharge capacity. According to many parties in the region this is a costly measure, which does not contribute to the spatial quality of the river landscape. Because of the regional objections to existing policies, a conflict emerged within the organization of Rijkswaterstaat between those who were responsible for the lowering of groynes, as an essential part of the national Room for the River programme, and those who stimulated discussion on alternative (spatial) strategies. Partly because of this conflict but also because of internal personnel changes within Rijkswaterstaat, the 4B pilot was terminated. At that time, a university professor, a former Rijkswaterstaat employee and member of the newly created regional network, took the initiative to continue the regional discussion on alternative flood risk management strategies. He also exploited the opportunity which was offered by a new national research programme on water management, 'Living with water'. On his initiative, regional parties drafted and got accepted a proposal for applied research. The research project WaalWeelde comprised the development of a joint vision (Stuurgroep WaalWeelde 2009), various strategies to better integrate water management and spatial planning (Braakhekke et al. 2007; Scholten 20II) and a website 'WaalWeelde wiki' to improve communication with citizens. The project initiative met resistance from some departments of Rijkswaterstaat, which were formally responsible for the lowering of groynes in the river Waal. Because the provincial government was interested in developing alternatives to the lowering of groynes, and in improving the spatial quality of the river landscape, the province became increasingly interested in the WaalWeelde initiative. The university professor established contact with the responsible provincial delegate who then started to play an active role in the WaalWeelde project. As a former MP, the provincial delegate had a good network in national government, started a successful lobby for the WaalWeelde project, and managed to acquire financial resources for the project initiative. After the completion of research the WaalWeelde project, the province of Gelderland took over the lead from the university professor quite naturally, and the provincial delegate began to chair the steering group WaalWeelde in which municipalities were represented by their eldermen. This was a logical step at the time, as research results had to be translated into regional and local policies. The project was divided into three regions: WaalWeelde East, Centre and West. Within these regions municipalities started discussing concrete options for creating more room for the river (for example, Stuurgroep WaalWeelde West 20II). In the meantime, after publication of the report by the influential Delta Committee (Deltacommissie 2008), the Dutch national government had started the Delta programme. The Delta programme aims to develop a set of policy measures to adapt to the consequences of climate change in the long run. Due to successful lobbying by the provincial delegate, and because of the bottom-up approach envisaged by the Delta programme, the steering group WaalWeelde was asked to develop policy alternatives for the river Waal and support formal governmental bureaucracy. 


\section{The Manhood Peninsula Partnership}

The Manhood Peninsula, which is situated in the south-east of England, is particularly vulnerable to sea level rise (Climate South East 2oII; Manhood Peninsula Partnership (undated)). Two residents, an immigrant Dutch landscape planner and a journalist, perceived a lack of integral governmental planning to deal with this issue, and building on their own connections started to contact private parties and landowners, and to build a network of people interested in land-use planning for the Peninsula. In the first instance, local and regional governments did not recognize the added value of the initiative, and were reluctant to cooperate or support the initiative financially (Scholten et al. forthcoming). Only after the two residents had established contact with the Dutch Association of Spatial Planners and managed to attract this organization's interest in the Peninsula's planning challenges did, among others, the relevant local body, the Chichester District Council (CDC), became interested in the idea. The residents further lobbied the West Sussex County Council (WSCC) and the Environment Agency (EA) and were successful in generating funds for organizing an international conference, on the basis of which the Manhood Peninsula Partnership was developed. After that, the partnership was also included in the EU-project ESPACE, which, for instance, enabled them to appoint a project manager and to develop a Climate Change Adaptation Action Plan. After the EA, CDC and the Arun District Council had developed a draft Coastal Defence Strategy, a second international workshop was organized to discuss the proposed strategy (Cobbold \& Santema 2008). The partnership was subsequently regularly consulted and came to play an active role in, among other things, a working group preparing a plan for coastal realignment, the Medmerry scheme (Environment Agency 20II). Today, the Manhood Peninsula Partnership has a board with representatives of, among others, the parishes, develops local small-scale projects and has a consultative role in the area with regard to coastal realignment. However, it has not been able to make an impact beyond the local level, as interviewees suggest, largely as a result of the few people directly involved at the council level and the many administrative levels that impact on water management.

\section{The Deltaplan for the dry rural areas}

Within the framework of the national ARK (Adaptation, Space and Climate; in Dutch: Adaptatie Ruimte en Klimaat) project, the Water Board Aa en Maas and the Province of Northern Brabant started discussing water scarcity and drought problems in the southern part of the Netherlands. The name of their regional project initiative was 'Help, de Peel verdroogt' ('Help, our Peel suffers from dessication'). De Peel is a dessicated nature area, thanks mainly to drainage of the surrounding agricultural lands. The chair of the Water Board played an initiating role in this project, contacted relevant parties, such as drinking water companies, agricultural organizations and nature organizations, and chaired the newly created steering group. One of the reasons behind the leading role of the Water Board was that the provincial delegate was skeptical about climate change at the time (Smits 20I3). The newly created steering group discussed adaptation challenges and possibilities to better attune water management and spatial planning, and aimed to gain the attention of national government for droughtrelated issues by preparing a joint reaction to the draft national Water Plan. The Water Board Aa en Maas, in cooperation with the project partners, also organized a symposium to draw attention to the issues of drought and water scarcity in 2009. The chairman of the national Delta Committee, which had issued an influential report on adaptation challenges in the water sector (see also the case study on WaalWeelde), took part in the conference. He asked regional actors to demonstrate leadership and to search for new solutions and governance approaches. In the aftermath of the symposium the steering group presented a strategy document titled 'A Deltaplan for the dry rural areas'. Within the project 'Deltaplan for the dry rural areas' regional actors started to assess potential impacts of climate change, to develop adaptation strategies, to enhance regional administrative support for the adaptation agenda, and to try getting water scarcity issues on the national agenda (Berkhuizen \& De Boer 20I0; Verheijen 20II). They also started a series of pilot projects, such as innovations in managing water tables and levels and realizing water storage capacity. The results of these pilots were presented at a second symposium, which was attended by the newly appointed national Delta Commissioner who is responsible 
for the implementation of the recommendations made by the Delta Commission. Just like the chair of the Delta Commission had done at the first symposium, the Delta Commissioner expressed his appreciation for the regional initiative, and called the project an important pillar of the subprogramme on the management of fresh water resources within the national Delta programme. The chair of the regional Water Board had played a major role in establishing connections with the national Delta programme. A main incentive to do so is that the Delta programme is linked to a special fund, which will be equipped with about one billion euros annually as from 2020. This money is being reserved for climate proofing the Netherlands, and although most of it will be spent to defend the country against sea and river floodings the region aims to direct at least part of it to dry rural areas. At the third symposium, which was organized in 2012 and attended by the Delta Commissioner again, the chair of the regional steering group stressed the need to start working on a joint investment programme for the next 20-30 years.

\section{Climate adaptation and the role of climate adaptation officers in northern Hesse}

The German KLIMZUG programme is a research programme aimed at developing innovative adaptation strategies. The regional programme KLIMZUG Northern Hesse, which was prepared by university researchers in cooperation with local and regional authorities, among other things entailed the introduction of a set of 'governance innovations'. One of these governance innovations was the appointment of climate adaptation officers (CAOs; in German: Klimaanpassungsbeauftragte) for a fixed term of five years. The main tasks of these officers were to raise awareness of adaptation issues, mainly within their 'host administrations' at the regional level and to initiate pilot projects (Bauriedl et al. 20IO; Bauriedl 20I2). After the proposal had been approved by the federal government, five CAOs were appointed and based within regional- and district-level government agencies. In spite of institutional support by the research programme, they all faced several problems during their first months within their respective agencies. The first problem was that many administrators were of the opinion that adaptation was nothing new and that they had been working on adaptation issues, such as drought issues, for a long time already. The basic attitude they encountered was that CAOs were welcome mainly because they were externally funded. Second, they faced difficulties in pinpointing the precise impact of climate change on this region. Unlike other parts of Germany, which are confronted with sea level rise or frequent river flooding, impacts for northern Hesse were less tangible (Bauriedl et al. forthcoming). For instance, an increasing likelihood of drought, heat stress and more extreme weather events were recognized as future issues, but their seriousness remains to be seen. Finally, the activities of CAOs were frustrated by the lack of financial resources for realizing adaptation projects. Whereas the five positions were funded by the federal KLIMZUG programme, no specific budget was allocated for the implementation of adaptation projects. During the first phase of their appointment the CAOs came to learn that rather than trying to build a new adaptation network, their main task was to link the adaptation agenda to other sectoral agendas. Depending on their position within their host agency, the CAOs started working on climate proofing spatial planning, or more specific implementation projects, such as the development of an innovative bus shelter which would reflect sunlight hence remain relatively cool on hot and sunny days. To gain support for their adaptation agenda, the CAOs often framed adaptation issues as public health issues, because these are usually taken more seriously than climate or environmental issues. According to the respondents, the CAOs managed to raise awareness of adaptation issues and fulfilled an important function by bringing the climate adaptation issue to the fore continuously. After the completion of the project in mid-2013, only few of the CAOs continued working for their host agency, and those who did went on working on adaptation issues part-time only. Yet, the project evaluation stressed that within their possibilities, CAOs have played a crucial role in getting adaptation on the local and regional governmental agendas (Bauriedl et al. forthcoming).

\section{DISCUSSION AND CONCLUSION}

To analyse the different manifestations of leadership in regional climate change adaptation, we have applied the leadership framework developed by Meijerink \& Stiller (20I3) 
and inspired by Complexity Leadership Theory (Uhl-Bien et al. 2007). The key feature of this framework is that it distinguishes five different leadership functions (and related leadership tasks), which need to be fulfilled within climate adaptation networks: the connective, enabling, adaptive, political-administrative and dissemination functions of leadership. The framework was drawn upon to answer our two research questions regarding: (1) the extent to which the five functions of leadership can be identified in practices of climate change adaptation and (2) which differences in the patterns of leadership exist between the cases initiated by governmental and non-governmental actors, respectively.

Table 2 lists the main actors who have contributed to the five leadership functions in each case study.

Comparing the main findings on the performance of leadership functions, the following conclusions can be drawn. First, in each case the actors who took the initiative fulfilled an important connective function. In the Dutch WaalWeelde initiative, the university professor played a crucial role in regional network formation and continuation. In the UK case of the Manhood Peninsula Partnership, two residents criticized the lack of integral planning they perceived for the Manhood Peninsula, and wanted government agencies to pro-actively develop visions on climate adaptation for this region. These active citizens managed to convene interested parties on the peninsula, and to initiate interaction between them. In the case of the Dutch Deltaplan for the dry rural areas, the chair of the Water Board took the initiative to develop a regional platform to discuss adaptation to drought and water scarcity. Finally, in the German case of northern Hesse, the climate adaptation officers contributed to the connective function by connecting the adaptation agenda to sectoral agendas to some extent. Interestingly, unlike in the other cases, they did not so much do this by developing novel forms of cooperation but rather by using existing networks.

By convening different actors and connecting their agendas, these initiators also fulfilled an important enabling function. In bringing different parties to the table, they helped to create the necessary condition for interaction. The fulfilment of enabling leadership, however, goes beyond connecting people and ideas only. We have seen that the recognition and exploitation of windows of opportunity, especially to generate necessary financial resources, was crucial to network development in three cases. In the WaalWeelde case, the university professor recognized the opportunity of a new national research programme, and in the Manhood Peninsula case study, participants in the network recognized the opportunity of European funding. In the dry rural areas case, the opportunities offered by the national Delta programme (and related budgets) were a main trigger for initiating a regional process, and the parties involved tried to acquire national resources for realizing

Table 2 | Leadership functions and observed leaders across the four cases (NB: the third row contains outcomes of the adaptive leadership function, not leaders)

\begin{tabular}{|c|c|c|c|c|}
\hline & WaalWeelde project initiative & $\begin{array}{l}\text { Manhood Peninsula } \\
\text { Partnership }\end{array}$ & Delta plan dry rural areas & KLIMZUG-northern Hesse \\
\hline Connective & $\begin{array}{l}\text { University professor; } \\
\text { Provincial delegate }\end{array}$ & Two active citizens & $\begin{array}{l}\text { Chair of the Water Board } \\
\text { Aa en Maas }\end{array}$ & Climate adaptation officers \\
\hline Enabling & $\begin{array}{l}\text { University professor; } \\
\text { Provincial delegate }\end{array}$ & $\begin{array}{l}\text { Two active citizens; } \\
\text { WSCC }\end{array}$ & $\begin{array}{l}\text { Chair of Water Board Aa } \\
\text { en Maas }\end{array}$ & Climate adaptation officers \\
\hline Adaptive & $\begin{array}{l}\text { Novel cooperation; } \\
\text { Development of new } \\
\text { spatial strategies }\end{array}$ & $\begin{array}{l}\text { Novel cooperation; } \\
\text { Development of } \\
\text { new spatial } \\
\text { strategies }\end{array}$ & $\begin{array}{l}\text { Novel cooperation; } \\
\text { Development of new } \\
\text { approaches through } \\
\text { pilot projects }\end{array}$ & $\begin{array}{l}\text { Initiation of adaptation pilots } \\
\text { and implementation projects }\end{array}$ \\
\hline $\begin{array}{l}\text { Political- } \\
\text { administrative }\end{array}$ & $\begin{array}{l}\text { Province of Gelderland; } \\
\text { Municipalities; Minister } \\
\text { for water management; } \\
\text { Delta commissioner }\end{array}$ & CDC; EA & $\begin{array}{l}\text { Chair and Executive of } \\
\text { Water Board Aa and } \\
\text { Maas; Provincial } \\
\text { Delegate and Executive }\end{array}$ & $\begin{array}{l}\text { Elected officials and civil } \\
\text { servants of the regions, } \\
\text { districts and the city of Kassel } \\
\text { (for some implementation } \\
\text { projects) }\end{array}$ \\
\hline Dissemination & $\begin{array}{l}\text { Provincial delegate; } \\
\text { University professor }\end{array}$ & Two active citizens & $\begin{array}{l}\text { Chair of the Water Board } \\
\text { Aa en Maas }\end{array}$ & Climate adaptation officers \\
\hline
\end{tabular}


their ambitions. In the northern Hessen case, the climate adaptation officers did not possess structural resources of their own, but, as part of their efforts to build sectoral implementation networks, sought to secure funding from the actors they were connecting (government and private actors) for specific projects.

Next to the initiators, who fulfilled an important enabling function by connecting people and by recognizing and exploiting windows of opportunity, in all four cases positional leaders performed enabling leadership as well, either by creating linkages to and lobbying other levels of government, by providing financial resources (thereby also fulfilling the political-administrative function) or by giving sufficient room for development to the newly developing adaptation networks. In both the WaalWeelde and the Manhood case studies we have seen that positional leaders may also play a reluctant enabling role that involves an element of assessment: in these two cases, government organizations and their positional leaders only started to support (and thus enable) the newly created initiatives once they had proven sustainable and successful to some extent.

The adaptive function of leadership refers to the development and emergence of new ideas and approaches in the interaction process within the networks. Our case studies include both governance innovations, such as the initiation of partnerships and new ways of cooperation, and more substantive innovations, such as development of new spatial planning strategies to adapt to climate change. In all four cases these different levels of innovations and development went hand in hand. The initiators of regional change processes all recognized the need for developing new strategies to cope with the regional impacts of climate change. At the same time, they were aware of the fact that new ways of cooperation across policy sectors, governmental levels and public and private parties can be important for developing such strategies. As the adaptive leadership function is defined as a result of group dynamics, it can often not be linked directly to the actions of particular individuals. Yet, some individuals, such as the active citizens initiating the Manhood Peninsula development, can be seen as crucial in initially providing new perspectives and ideas although they were not able to determine the outcome of the interaction process.

The hesitant or cautious attitude of many positional leaders proved challenging to the political-administrative function, which can only be fulfilled by positional leaders. We have seen that positional leaders still played a crucial role in decision-making on visions, plans and implementation projects at a later stage. In the WaalWeelde and Manhood Peninsula cases positional leaders - once they started supporting the initiatives - have played a crucial role in decision-making and generating funding for the plans developed in the WaalWeelde network, and in the Manhood Peninsula case, for determining the formation of the partnership and finding financial resources for it. In the case of the Deltaplan for the dry rural areas, the political-administrative function is recognized as important by participants, but, except for decision-making on a strategy document, the initiative has not yet reached the phase of decision-making on concrete measures. The Chair of the Water Board fulfilled the dissemination function by establishing links with the National Delta programme, while in the WaalWeelde case the provincial Delegate fulfilled a similar function by linking the WaalWeelde project initiative to the National Delta Programme. Both of these cases thus provide examples of linkages to regional and national levels of government. In the case of CAOs in German northern Hesse, the political-administrative function was fulfilled by local and regional government decision-makers for the realization of some small-scale pilot and implementation projects, such as mosquito and tick warning systems and bus shelter adjustments, while CAOs to some extent fulfilled the dissemination function when successfully lobbying government decision-makers and other actors for ideas they had helped to develop.

In relation to our first research question, we may conclude that all five functions can be identified in all cases. We may also conclude from Table 2 that even though we have identified key actors in each case study, leadership in many of the cases was fragmented: leadership functions that played a role in developing the initiatives to their present state were partly fulfilled by different actors. This finding shows the added value of the complexity leadership perspective, which, rather than focusing on individuals, draws attention to the functions that need to be fulfilled within networks.

The identification of leadership functions in the cases provides a reason to reflect on the theoretical framework presented in Figure 1. In a first application of the framework 
(Scholten et al. forthcoming), we concluded that in the case studies of Waalweelde and the Manhood Peninsula it was difficult to distinguish analytically between the connective and enabling functions of leadership. The same conclusion can be drawn for the newly studied cases of the Deltaplan for the dry rural areas and KLIMZUG northern Hesse. Table 2 shows that all actors who contributed to the connective function also contributed to the enabling function. In all four cases, actors enabled the change process by connecting organizations and people. Therefore, based on our case study findings, we propose to revise the model presented in Figure 1, and to integrate the connective function within the enabling function of leadership (see Figure 2).

Having discussed the general pattern of how various actors can be seen as contributing to the leadership functions, we turn to the question whether we may observe similarities or differences in the patterns of leadership in the adaptation practices initiated by governmental and non-governmental actors, respectively. In the WaalWeelde and Manhood Peninsula case studies, the main drivers were located outside the sphere of governmental actors. A university professor and two active citizens, respectively, with the help of others, started to build innovation networks, thereby challenging governmental bureaucracies and existing policies. Their main challenge was to establish links between the newly created innovation networks and the governmental organizations, which would need to support the proposed approaches. In both cases, the initiators demonstrated perseverance and invested a lot of time and energy in their change projects, which may explain why they managed - at least partially - to gain support for their partnerships by policy and decision-makers: while limited with regard to the demands of overarching policy requirements, the Manhood Peninsula partnership was given a

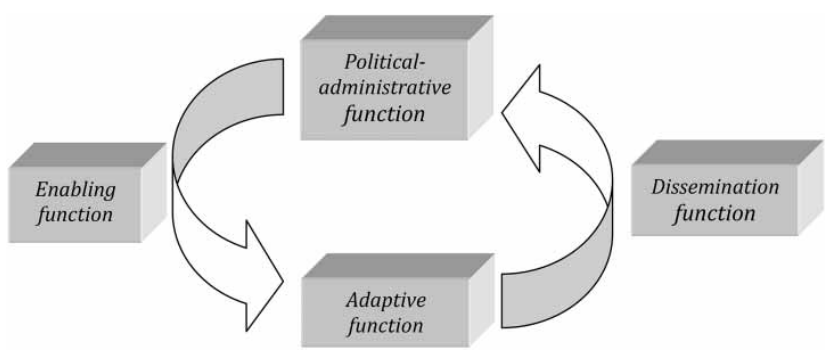

Figure 2 | Revised framework of leadership functions for climate adaptation. role in other land use planning development, and the steering group WaalWeelde was integrated in the national Delta programme.

This pattern is different from the cases in which governmental actors were the main drivers behind the initiatives. In the Dry rural areas case, the first steps were taken by a positional leader, the chair of a Water Board. Unlike the initiating actors in the Waalweelde and Manhood Peninsula cases, he had direct access to decision-making arenas. Because of this position he was also able to mobilize the political-administrative network, to establish a steering group and project management structure within the governmental bureaucracies, and to connect with the national Delta Programme. However, despite these advantages it remained difficult to gain considerable political-administrative support for innovative adaptation strategies. In the German northern Hesse case, unlike the chair of the Water Board in the Netherlands, the CAOs were not positional leaders themselves. Although they were employed by the regional government agency and operated from within regional, district and city administrations, they lacked working experience in public administrations. However, similar to the chair of the Water Board they faced the challenge of influencing agendas and, in this respect, changing the governmental organization from within in the absence of serious external pressure. Some of the obstacles to leadership functions in this case could potentially result from the fact that it differs from the other three cases involving emergent (spontaneous) leadership by key individuals in that the CAOs were purposively appointed and given the specific tasks to raise awareness and to initiate pilot projects. According to complexity leadership theory, leadership is defined through action, and not through the possession of a specific position. Analogous to the argument that positional leaders need not always exercise effective leadership, their very appointment as CAOs does not automatically qualify them as leaders. Yet, we found that they actually fulfilled some important leadership functions (enabling/connective) hence they demonstrated leadership.

In summary, while a key difference between processes initiated by governmental and non-governmental actors, respectively, was that non-governmental actors needed to invest much more time and energy in gaining access to formal decision-making arenas, innovation processes 
which were initiated by governmental actors, who had good access to formal decision-making arenas, did not necessarily lead to a smoother translation of the innovations into formal policies.

The studies in this regard evidence the role of factors external to the leadership functions: whereas in the first two cases bottom-up change dynamics created considerable external pressure pushing the governmental actors towards change, in the latter cases the key actors faced the challenge of convincing other actors without such external pressure.

The case studies initiated outside government concerned flooding issues that have a relatively high sense of urgency which presumably also supported the involvement of governmental actors expressing leadership functions in these cases (even though no flood events took place within the time frame of the case study). The governmental initiator cases primarily concerned heat and drought issues, for which the sense of urgency seems to be relatively low. While we have not investigated this systematically, the sense of urgency may, in line with for instance agenda-setting theoretical frameworks (e.g., Kingdon 1984), be relevant to understanding formal leadership dynamics as well. Thus, the various leadership functions may be fulfilled more easily - and positional leaders may also more easily accommodate initiatives outside formal structures - when the sense of urgency is high (see e.g., Keskitalo et al. 20I2). The study can thus be seen as contributing to the existing literature on the difficulties of developing initiatives beyond incremental adaptations to climate change (e.g. Kates et al. 20I2; Keskitalo 20I3).

Finally, we are aware that along with many similarities there also are institutional differences between the three countries included in our study. These include state structure and culture: for instance, the German federal state structure versus the unitary state structure in the Netherlands, and the German legalistic administrative culture compared with the Dutch consensus decision-making culture. In addition, the role of water and adaptation in planning may differ between the countries (cf. Keskitalo 2010a, 20IOb). While the administration in the Netherlands has to a great extent targeted water issues, water management is comparatively less central to the (at the time of the study) relatively complex and multi-level planning framework in the UK (cf. Keskitalo 20I0a, 20Iob; Scholten et al. forthcoming). In our research, we have concluded that the leadership functions were present in all four cases studied, and that the fulfilment of these functions posed different challenges to governmental and non-governmental actors who wanted to initiate a change process. Even though we have not found indications that specific leadership functions are more or less important within one country as compared with others, the specific ways in which actors fulfil these functions may differ across different institutional settings. More research on the relationship between structural and cultural characteristics of governance systems and leadership behaviour is needed to learn more about this.

\section{ACKNOWLEDGEMENTS}

This paper is part of the ongoing research project 'Governance of adaptation to climate change', which is funded by the Dutch research programme 'Knowledge for Climate'. We are also grateful to Riksbankens Jubileumsfond in Sweden for funding the Manhood Peninsula case study, and to the Department of Geography and Economic History at Umeå University, Sweden for funding extended studies of the WaalWeelde case.

\section{REFERENCES}

Allen, K. E., Stelzener, S. P. \& Wielkiewicz, R. M. 1998 The ecology of leadership: adapting to the challenges of a changing world. J. Lead. Stud. 5, 62-82.

Bauriedl, S. 20I2 Promotors of local adaptation governance: formal and informal cooperation in actor networks. Paper for the International Symposium The Governance of Adaptation, 22-23 March 2012, Amsterdam, The Netherlands.

Bauriedl, S., Müller, T. \& Schneider, K. 2010 Klimaanpassungsbeauftragte in nordhessischen Landkreisen: eine neue Institution als Reaktion auf den Klimawandel. In: Governance in der Klimaanpassung-Strukturen, Prozesse, Interaktionen (P. Cormont \& S. Frank, eds). Dokumentation der Tagung der KLIMZUG-Verbünde an der TU Dortmund, 3-12-2010, pp. 90-93.

Bauriedl, S., Krebs, F., Hafner, S., Mauritz, C., Pansa, R., Walther, M. \& Weidlich, S. forthcoming Evaluation der GovernanceInnovationen in Nordhessen. In: Abschlusspublikation KLIMZUG-Nordhessen (A. Roßnagel, ed.). Schriftenreihe 'Interdisciplinary Research on Climate Change Mitigation and Adaptation', Kassel University Press, Kassel, Germany (i.E.). 
Berkhuizen, H. \& De Boer, S. 2010 Naar een Deltaplan voor hoge zandgronden. $\mathrm{H} 2 \mathrm{O} 3,12-14$.

Biermann, F., Abbott, K., Andresen, S., Bäckstrand, K., Bernstein, S., Betsill, M. M., Bulkeley, H., Cashore, B., Clapp, J., Folke, C., Gupta, A., Gupta, J., Hass, P. M., Jordan, A., Kanie, N., Kluvankova-Oravska, T., Lebel, L., Liverman, D., Meadowcroft, J., Mitchell, R. B., Newell, P., Oberthur, S., Olsson, L., Pattberg, P., Sanchez-Rodriguez, R., Schroeder, H., Underdal, A., Camargo Vieira, S., Vogel, C., Young, O. R., Brock, A. \& Zonderva, R. 2012 Navigating the anthropocene: improving earth system governance. Science 335 (6074), 1306-1307.

Braakhekke, W., Litjens, G., van Winden, A., van Nieuwenhuijze, L., te Molder, M., van der Krogt, M., Hoogvliet, M., Cohen, J. \& Gruijters, S. 2007 InspiratieAtlas WaalWeelde, WaterInnovatiebron, Rijkswaterstaat, InnovatieNetwerk, Utrecht.

Chrislip, D. 2002 The Collaborative Leadership Fieldbook: A Guide for Citizens and Civic Leaders. Jossey-Bass, San Francisco, CA.

Climate South East 2oII Manhood Peninsula Partnership. http:// www.climatesoutheast.org.uk/index.php/case/case_detail/ manhood_peninsula partnership (accessed 28 October 2013).

Cobbold, C. \& Santema, R. 2008 Going Dutch II. Towards a Safe and Sustainable Future of the Manhood Peninsula. Manhood Peninsula Partnership, Chichester.

Deltacommissie 2008 Working Together with Water: A Living Land Builds for its Future. Findings of the Deltacommissie. Deltacommissie, Rotterdam.

De Rooij, A. (ed.) 2000 Fysica van samenwerking: Naar een krachtenfusie van burgers, bestuurders, bureacraten en bedrijven. Rijkswaterstaat, Den Haag.

Environment Agency 20II Medmerry Managed Realignment Scheme. http://www.environment-agency.gov.uk/ homeandleisure/floods/109062.aspx (accessed 28 October 2013).

IPCC 2014 Climate Change 2014 Impacts, Adaptation, and Vulnerability. http://ipcc-wg2.gov/AR5/report/final-drafts (accessed 7 April 2014).

Kates, R. W., Travis, W. R. \& Wilbanks, T. J. 2012 Transformational adaptation when incremental adaptations to climate change are insufficient. PNAS 109 (19), 7156-7161.

Keskitalo, E. C. H. 20Ioa Introduction: adaptation to climate change in Europe - theoretical framework and study design. In: The Development of Adaptation Policy and Practice in Europe: Multi-level Governance of Climate Change (E. C. H. Keskitalo, ed.). Springer, Dordrecht, pp. 1-38.

Keskitalo, E. C. H. 2orob Climate change adaptation in the United Kingdom: England and South-East England. In: The Development of Adaptation Policy and Practice in Europe: Multi-level Governance of Climate Change (E. C. H. Keskitalo, ed.). Springer, Dordrecht, pp. 97-147.

Keskitalo, E. C. H. 2013 Conclusion: Flood management and adaptation - viewing flood events in context. In: Climate
Change and Flood Risk Management: Adaptation and Extreme Events at Local Level (E. C. H. Keskitalo, ed.). Edward Elgar, Cheltenham, pp. 290-308.

Keskitalo, E. C. H., Westerhoff, L. \& Juhola, S. 2012 Agenda-setting on the Environment: the development of climate change adaptation as an issue in European States. Environ. Policy Gov. 22 (6), 381-394.

Kingdon, J. W. 1984 Agendas, Aalternatives and Public Policies. Harper Collins, New York.

Luke, J. S. 1998 Catalytic Leadership: Strategies for an Interconnected World. Jossey-Bass, San Francisco, CA.

Luke, J. S. 2000 Policy leadership. In: Defining Public Administration: Selections from the International Encyclopedia of Public Policy and Administration (J. M. Shafritz, ed.). Westview Press, Boulder, CO, pp. 51-55.

Manhood Peninsula Partnership. Undated The Manhood Peninsula Partnership - Achievements. Manhood Peninsula Partnership, Chichester District Council, Chichester.

Mees, H. L. P. \& Driessen, P. P. J. 20II Adaptation to climate change in urban areas: Climate-greening London, Rotterdam, and Toronto. Clim. Law 2, 251-280.

Meijerink, S. \& Stiller, S. 2013 What kind of leadership do we need for climate adaptation? A framework for analysing leadership objectives, functions, and tasks in climate change adaptation. Environ. Plann. C 31, 240-256.

Mintrom, M. I997 Policy entrepreneurs and the diffusion of innovation. Am. J. Polit. Sci. 41, 738-770.

Osborn, R. \& Hunt, J. 2007 Leadership and the choice of order: Complexity and hierarchical perspectives near the edge of chaos. Lead. Q. 18, 319-340.

Scholten, P. H. T. 2orr Daring leadership, A study of water governance on the edge of innovation and democracy. PhD thesis, Radboud University Nijmegen, Nijmegen, The Netherlands.

Scholten, P., Keskitalo, E. C. H. \& Meijerink, S. forthcoming Bottom-up initiatives on climate change adaptation in cases in the Netherlands and the UK: A complexity leadership perspective. Environ. Plann. C.

Smit, B. \& Wandel, J. 2006 Adaptation, adaptive capacity and vulnerability. Global Environ. Change 16, 282-292.

Smits, R. 2013 Wie regisseert hier eigenlijk? Onderzoek naar de rol van de Provincie Noord-Brabant bij het deltaplan Hoge Zandgronden. Master thesis Spatial Planning, Raboud University Nijmegen, Nijmegen School of Management.

Stuurgroep WaalWeelde 2009 Visie WaalWeelde, December 2009.

Stuurgroep WaalWeelde West 2oII Startnotitie Structuurvisie/ MER WaalWeelde West, uitgangspunten en reikwijdte detailniveau m.e.r.

Taylor, A., Cocklin, C. \& Brown, R. 2012 Fostering environmental champions: A process to build their capacity to drive change. J. Environ. Manage. 98, 84-97.

Uhl-Bien, M., Marion, R. \& McKelvey, B. 2007 Complexity leadership theory; Shifting leadership from the industrial age to the knowledge era. Lead. Q. 18, 298-318.

Van Nieuwaal, K., Driessen, P., Spit, T. \& Termeer, K. $2009 A$ State of the Art of Governance Literature on Adaptation to 
Climate Change: Towards a Research Agenda. Knowledge for Climate report 3/2009, National Research Programme Knowledge for Climate, University of Utrecht/Wageningen University.

Verheijen, L. 20II Watergovernance in Noord-Brabant, Balanceren tussen belangen en bestuurslagen: Reflecties op 30 jaar werken aan water. In: Kwartiermakers van de toekomst (J. van den Berg, Y. Deelstra, W. Kesseler, S. Nooteboom \& G. Teisman, eds). Uitgeverij Mastercircle, Deventer, pp. 178-192.
Warner, J. 2008 Emergency river storage in the Ooij-polder - a bridge too far? Forms of participation in flood preparedness policy. Int. J. Water Resour. Dev. 24 (4), 567-582.

Wielkiewicz, R. M. \& Stelzner, S. P. 2010 An ecological perspective on leadership theory, research and practice. In: Leadership for Environmental Sustainability (B. W. Redekop, ed.). Routledge, New York, pp. 17-35.

Wreford, A., Moran, D. \& Adger, N. 2oIo Climate Change and Agriculture: Impacts, Adaptation and Mitigation. OECD Publishing.

First received 15 November 2013; accepted in revised form 23 June 2014. Available online 6 August 2014 